\title{
KLIMATSKA PISMENOST: ANALIZA OSNOVNIH PREPREKA RAZVOJU I ŠIRENJU KLIMATSKE PISMENOSTI
}

\author{
Vladimir Lay
}

\author{
Izidora Kršnjavoga 8c, 47000 Karlovac \\ e-mail: lay.vladimir88@gmail.com
}

\begin{abstract}
„Niti jedan problem ne može biti riješen iz onog tipa 'mind-seta' iz kojeg je nastao. Moramo stvari vidjeti na novi način."
\end{abstract}

Albert Einstein

\begin{abstract}
Sažetak
U središtu pozornosti članka odnos je procesa rastućeg globalnog zagrijavanja i klimatskih promjena, među najvecim problemima suvremene civilizacije, i razvoja klimatske pismenosti, kao jedne od glavnih pretpostavki i alata ovladavanja ovim problemom. Tema klimatske pismenosti danas je u fazi iniciranja u formalnim i neformalnim obrazovnim praksama diljem svijeta. Rezultata sustavnih istraživanja ovih praksi u ovoj fazi, logično je, još nema.

Definicija klimatske pismenosti koju ocjenjujemo uvjerljivom i korisnom u budućoj praksi klimatskog opismenjavanja glasi: „Klimatski pismena osoba: a) razumije osnovna načela planetarnog klimatskog sustava; b) zna kako doći do znanstveno vjerodostojnih informacija o klimatskim promjenama; c) komunicira o klimi $i$ klimatskim promjenama na adekvatan $i$ razumljiv način; i d) sposobna je učiniti utemeljene $i$ odgovorne odluke u vezi s akcijama koje mogu utjecati na klimu u smjeru smanjenja stakleničkih plinova i smanjenja globalnog zagrijavanja" (NOAA, 2009). Prosječna klimatska pismenost, prema našoj općoj ocjeni, u suvremenoj je civilizaciji na niskoj razini. Za to nemamo potvrde u rezultatima istraživanja jer njih na ovu temu gotovo da i nema. Sustavno pogoršanje na polju globalnog zagrijavanje indirektno potvrduje ovu procjenu. Klimatska pismenost suvremenih društava još ne pokreće bitne tehnologijske, organizacijske i društvene promjene ka smanjenju stakleničkih plinova. Osnovne zapreke u razvoju klimatske pismenosti sa sociologijskog motrišta su: a) Percepcija modernih ljudi je sužena, kasni za činjenicama, globalno zagrijavanje $i$ klimatske promjene su kažu oni - problem budućnosti! Klimatskim opismenjavanjem ćemo se baviti kada to bude aktualno; b) Učinkovit i organizirani politički globalni odgovor na problem globalnog zagrijavanja godinama je izostajao. To je, najkraće rečeno, odgodilo ili barem usporilo razvoj i širenje klimatske pismenosti; c) Klimatsko će opismenjavanje više potaknuti rastuće negativne posljedice globalnog zagrijavanja nego metoda anticipacije budućih posljedica klimatskih promjena; i d) "Prevodenje "znanstvenih nalaza, podataka i spoznaja o globalnom zagrijavanju i klimatskim promjenama „običnim“ stanovnicima svijeta i pojedinih društava $i$ država je neućinkovito.
\end{abstract}

Ključne riječi: klimatska pismenost, globalno zagrijavanje, klimatske promjene 


\section{PRETHODNA NAPOMENA}

Globalno zagrijavanje Zemlje, našeg zajedničkog doma sustavno i stalno raste. Klimatske promjene kao posljedica toga procesa po opsegu i intenzitetu također stalno rastu i tako postaju problem „broj 1“ modernog čovječanstva. Znamo li „čitati“ što se zbiva i znamo li što treba činiti da bi se ovaj rast zaustavio? Klimatska pismenost modernih ljudi je na niskoj razini. Klimatska je pismenost suvremenih društava, unatoč razvijenim obrazovnim sustavima, vrlo slaba. Tema klimatskih promjena nije prisutna ni u školama, ni na kolegijima na fakultetima. Moderni mediji, utjecajan izvor informacija i formiranja stavova dotiču se ove teme sporadično, uglavnom senzacionalistički. Politički upravitelji država i svijeta još nisu uvjerljivo pokazali da su čvrsto odlučili nešto poduzeti da dođe do promjene. Poduzetništvu koje se brine za profit klimatske promjene nisu u žarištu pozornosti pa odatle niti poseban predmet djelovanja. U takvom poretku stvari klimatsko opismenjavanje nije do sada moglo uzeti maha.

U biti, klimatske su promjene postale „kost u grlu“ kapitalističke civilizacije, profit pod svaku cijenu i rast kao neupitan cilj, čak dogma, vode ukupni razvoj na Zemlji u „slijepu ulicu“" Naomi Klein, kanadska sociologinja tvrdi da klimatske promjene mijenjaju sve i da je „kapitalizam protiv klime“. ${ }^{1}$

Način na koji civilizacija razvija klimatsku pismenost je za sada temeljno neučinkovit, jalov. Kao da bi masovno i sustavno klimatsko opismenjavanje bilo protiv kapitalizma, njegovih vrednota, interesa i ciljeva?!2 Potrebno je skrenuti pozornost na ovu temu, obuhvatiti je i uključiti svim raspoloživim, aktivnim znanjem i pameću te zalaganjem za Život kako bi se dogodile promjene.

Ovakva situacija i ovakvi odnosi temu klimatske pismenosti po našoj procjeni čine stručno, znanstveno i životno važnom i značajnom. Socijalna ekologija, a posebno novonastala sociologija klimatskih promjena ima priliku dati koristan spoznajni doprinos.

\section{2. ŠTO SE DOGAĐA?}

Globalno zagrijavanje raste, a iz neprimjetno povećanih temperatura pokreću se klimatske promjene koje se tiču mora, vode, tla, zraka, vegetacije, faune, krajolika i ljudi. Količine stakleničkih plinova ${ }^{3}$ se u našoj atmosferi stalno, desetljećima gomilaju. Mnogim pojedincima to još nije jasno. Suvremeni ljudi često nemaju širu sliku, nemaju valjanih informacija i saznanja. Isto tako, što svjesno, a što neosviješteno čuvaju svoje „viso-

\footnotetext{
1 Objašnjenje ove teze daje Naomi Klein (2015).

2 Klein u spomenutoj knjizi piše: „Ističemo vezu između kapitalizma i klimatskih promjena zato što nam činjenica da se sustavi za održavanje života planeta destabiliziraju govori da postoji nešto potpuno krivo u našem ekonomskom sustavu" (Klein, 2015).

3 Staklenički plinovi su ugljični dioksid, metan, di-dušik oksid, CFC, HCFC i još neki u manjim razmjerima. Budući da je ugljični dioksid najzastupljeniji plin, uvriježilo se govoriti o pojmu "nisko-ugljični“ / „visoko-ugljični“ (razvoj, strategija i sl.). Pravilnije je govoriti o „nisko-emisijskim“ ili „visoko-emisijskim“ procesima, stanjima i sl.
} 
ko-ugljične“ / „visoko-emisijske“ dugogodišnje navike i ignoriraju prijedloge promjene ponašanja čuvajući te navike i svoje uske interese. Jake interesne grupe, koje se nazivaju „karbonkracijom“ promiču fosilna goriva, brinu za visoke zarade. Ugrožavanje klime stakleničkim plinovima koji se su-proizvode u procesu potrošnje fosilnih goriva ih ne zanima. Tko vidi samo dio, ne vidi cjelinu. Klima je (naša zajednička) cjelina. Pitanje cjeline se ne može isključiti iz žarišta pozornosti i djelovanja bez loših posljedica.

Zamislimo da nas netko mudar i pametan motri iz nekog drugog sustava u Svemiru - i što vidi? Vidi mnogo neznanja i uskih, čudnih i nelogičnih, sitnih interesa, pomalo bezumnih, izrazito dugoročno neodrživih oblika ponašanja i djelovanja, vidi učinke koji dugoročno postaju razorni po goli opstanak Života na toj lijepoj i maloj planeti.

Traži se nova planetarna svijest kojoj je temeljna potka nova pismenost. Nazovimo je planetarna klimatska pismenost. Nedvojbeno je da većina ljudi moderne civilizacije ima nisku razinu klimatske pismenosti i ne razumije što se događa te stoga niti ne mijenja svoje navike i ponašanje. Pitajmo, uostalom sami sebe - jesmo li klimatski pismeni?

Dugo, sporo i s mnogo sumnji je otkrivana i priznavana istina, činjenica da globalno zagrijavanje proizvode ljudi svojim djelovanjem. Ujedinjeni narodi 1988. godine klimatske promjene proglašavaju „zajedničkom brigom čovječanstva“ i stvaraju Međuvladin panel o klimatskim promjenama (IPCC). IPCC svijetu predstavlja rezultate mjerenja stakleničkih plinova, znanstvene spoznaje i prognoze. Od prvog izvješća IPCC ${ }^{4}$ objavljenog 1990. prošlo je četvrt stoljeća. U izvještaju iz 2003. godine konačno piše: " $\mathrm{Za}$ grijavanje klimatskog sustava je neupitno, a prema zadnjem izvješću, mnogo promatranih promjena od 1950-ih je bez presedana ne samo desetljećima, već i tisućljećima. Stručnjaci su potvrdili uzroke tog fenomena: 'Utjecaj čovjeka na klimatski sustav jasno je utvrden".

Posljedice globalnog zagrijavanja su mnogobrojne i različite: poplave, suše, snažne oluje, uragani i drugi razorni procesi kao toplinski udari, promjene u ponašanju biljnog i životinjskog svijeta. Tijekom 2015. godine prijeđena je granica emitiranja $\mathrm{CO}_{2} \mathrm{u}$ atmosferu od $400 \mathrm{ppm}$ (ppm = čestica na milijun). Podsjetimo se, „pulsiranje“ $\mathrm{CO}_{2} \mathrm{u}$ atmosferi za proteklih 400000 godina nije tijekom povijesti planeta nikada prelazilo $300 \mathrm{ppm}$ da bi 1993. doseglo 357 ppm-a i do danas se popelo na preko 400 ppm-a. Nepovoljan je to i pomalo već opasan trend.

Posljednjih 10 godina, od 2005. do 2015. bile su među najtoplijima u povijesti mjerenja. Godina 2015. je bila daleko najtoplija otkad se krajem 19. st. počela mjeriti temperatura. Prosječna temperatura kopna i mora za čitavu 2015. bila je 0,9 Celzijevih stupnjeva iznad prosjeka za 20. stoljeće, što je najviše od početka mjerenja 1880. Napokon, utvrđeno je da je prosinac 2015. bio najtopliji mjesec u zadnjih 136 godina. U prvoj polovici 2016. godine ovaj se je trend nastavio. Američka nacionalna oceanografska i atmosferska služba (NOAA) objavila je u kolovozu 2016. da je ovogodišnji

4 ICCP $=$ Međuvladino tijelo za klimatske promjene (engl. Intergovernmental Panel for Climate Changes). ICPP je znanstveno tijelo koje proizvodi znanstvene izvještaje o stanju emisija stakleničkih plinova i njihovim posljedicama te na temelju trendova daje prognoze i preporuke COP-u, dakle konferenciji učesnika koji donose političke odluke. 
srpanj do sada najtopliji zabilježeni srpanj, a ujedno i najtopliji mjesec otkad se bilježe podaci (NOAA, 2016).

Dakle, što se događa? Što možemo zaključiti? Ljudska rasa svojim djelovanjem razara prirodne osnove života na Zemlji, ono bogatstvo zbog kojeg je život na ovom planetu uopće i nastao. Osnovni uzrok ovog negativnog procesa je u tome što moderne tehnologije i suvremena organizacija življenja u urbanim i ruralnim dijelovima planet Zemlje su-proizvode stakleničke plinove koji u atmosferi remete prirodne ritmove i prosječnu, prirodnu temperaturu planeta. Nastaju klimatske promjene koje imaju široku paletu oblika, od suša do velikih i razornih oluja, diljem Zemlje. ${ }^{5}$

Nije se još razvila spoznaja i svijest o povezanosti / zbroju svih emisija stakleničkih plinova u zemljinoj atmosferi na planetarnoj razini. Postoje socijalne snage i interesi koji razvoj i širenje ove spoznaje usporavaju ili čak onemogućavaju. Istina je da samo deset zemalja u svijetu emitira oko $50 \%$ stakleničkih plinova i da mnoge male i slabije razvijene zemlje imaju veoma male emisije. Hrvatska emisija kreće se ispod $0,1 \%$ od ukupnih svjetskih emisija stakleničkih plinova. No, bit problema je jednostavna - problem globalnog zagrijavanja je problem kumulacije svih emisija iz svih zemalja. Političke i geografske granice tu ne igraju nikakvu ulogu. Povratno se kao problem klimatskih promjena i njenih konkretnih „udarnih“ oblika ovaj kumulativ vraća svima, manje ili više, na ovaj ili onaj način, danas tu - sutra tamo.

Što će se dogoditi ukoliko se postojeći rastući trend gomilanja stakleničkih plinova u atmosferi Zemlje i porast globalne temperature, kakav je na djelu posljednjih 200, a posebno posljednjih 50 godina, nastavi istim ili većim tempom u narednim desetljećima? Imat ćemo za izravnu posljedicu usporeno, a potom sve brže, vrlo kompleksno i po oblicima raznovrsno ranjavanje i pojave ubijanja živog svijeta i Života na Zemlji.

Ovaj proces kapitalistička civilizacija, bila ona toga svjesna ili ne, stalno proizvodi u tkivu ukupnog načina organizacije produkcije i načina života, oslonjena na tehnologije i fosilna goriva čije sagorijevanje proizvodi stakleničke plinove. Orijentacija na rast, na brza, velika i stalna povećanja količine dobara i usluga te prekomjerna potrošnja sve većeg broja ljudi na planetu Zemlji osnažuje visoko-ugljične, odnosno visoke emisije stakleničkih plinova koje su danas dio toga rasta. Zaključak: ljudska rasa je svojim učincima, ne znajući u početku što radi, prodrla u planetarni mehanizam Prirode kao vrhunskog fizičkog / materijalnog činitelja i regulatora Života i živog svijeta na Zemlji. Ušavši u njega, u njegovu utrobu, počela je taj mehanizam Prirode razgrađivati i razarati iznutra.

Politički vladari i upravljači, donositelji razvojnih odluka moćnih država, multinacionalne kompanije te vojno-industrijski kompleksi su, kako zorno vidimo, pretežno „zabavljeni“ borbom za geopolitički utjecaj i premoć, desetljećima proizvodeći sukobe i ratove, razaranja i masovne migracije. Mali narodi tu nemaju utjecajnu ulogu. Poslovni ljudi, poduzetnici svijeta pak ne mare odviše za problem globalnog zagrijavanja. Djeluju

5 ICCP od vremena do vremena proizvodi detaljne i opsežno dokumentirane znanstvene izvještaje o stanju planetarne klime. Posljednji takav je onaj pod naslovom „Climate Changes - Synthesis Report 2014“. 
u planetarnom kapitalističkom pogonu i stvaraju neophodni višak vrijednosti za gospodarski rast, potrošnju i povećanje kvalitete življenja. Paralelno stvaraju i velike profite za vlasnike - za uske grupe ljudi, a profitom pod svaku cijenu nesmiljeno i neodrživo troše, ranjavaju i doslovno uništavaju prirodne osnove života i milijune ljudi. Podataka i dokaza na ovu temu ima na tisuće i tisuće samo u jednoj godini. Njihovu spoznaju o rizicima od globalnog zagrijavanja zastiru profit, a nerijetko i pohlepa. ${ }^{6}$ Pohlepni inače ne vide šire, ovdje pak ne vide kontekstualne planetarne pretpostavke vlastita djelovanja i probleme opstanka svih ljudi. To ih se, misle takvi, ne tiče.

Ukratko, upravljačke elite kako političke tako i poduzetničke dominantno se u odnosu na globalno zagrijavanje i klimatske promjene ponašaju po „BAU“ modelu: Sutra ćemo raditi onako kako smo radili jučer (engl. bussiness as usual). Postojeći sustavi reprodukcije života su velikim dijelom „zaključani “7 , zaglavljeni u zastarjelim načinima mišljenja. Načinima produkcije vladaju partikularni, ali vrlo moćni interesi koje se ne može mijenjati ili rušiti preko noći. Ovi interesi su izravno suprotni općem interesu svih za zaustavljanjem i sprečavanjem porasta klimatskih promjena. Zaključno, politički i poduzetnički vladari i upravljači, ti moderni slijepci, ne baš mudro, hrabro i pohlepno kroče u neki njihov „naprijed“. Bez obzira na riječi i deklaracije de facto u globalnom zagrijavanju i klimatskim promjenama još uvijek ne vide temeljne makro-ekološke opasnosti koje svima nama na Zemlji prijete dubinskim i nepovratnim poremećajima klime, odnosno mnogobrojnim destruktivnim ekstremnim klimatskim procesima, štetnim za život i imovinu. Stvarni „neprijatelj“ prijeti svima, ali „iznutra“, a ne „izvana“, iz smjera vlastitih unutrašnjih struktura i metoda reprodukcije života koje su sami stvarali dva stoljeća. Opak je to „neprijatelj“, direktno vezan za odsustvo ili slabosti ljudske pameti, mudrosti, dalekovidnosti i volje za promjenom, uključivo ovdje i slabu volju za klimatskim opismenjavanjem.

Poznavanje uzroka i posljedica globalnog zagrijavanja i klimatskih promjena, uočavanje ključnih točaka moguće promjene koje bi vodile ka mijeni ovog negativnog procesa je na niskoj razini. ${ }^{8}$ Odatle klimatska pismenost postaje relevantna tema kojoj socijalna ekologija i novonastala sociologija klimatskih promjena itekako ima što reći.

6 „Radix Ominum Malorum Avaritia“ - Korijen svih zala jest u pohlepi (Sv. Pavao, Prva poslanica Timoteju 6:10).

7 Takvi sustavi su na primjer centralizirana proizvodnja električne energije, čelični automobili pogonjeni na fosilna goriva i drugi. Vožnje automobilom na fosilna goriva ne mora biti do kraja svijeta, ali napustiti danas ili odmah sutra naftu i partikularne, ali moćne interese prodavača nafte i tehnologija iz nje izvedene (moderni automobil je jedan dobar primjer), lako je razumjeti, naprosto ne ide! Otpori su danas još golemi, čak i kada pomalo slabe a nove tehnološke solucije i alternative kroz obnovljive izvore energije ekološki, ali i ekonomski postepeno jačaju.

8 U razdoblju od 2007. do 2016. godine održali smo oko 90-100 javnih predavanja o ovoj temi. U početku, od 2007.-2009. bila je riječ o učenicima srednjih škola diljem Hrvatske (u okviru projekata - podatke vidi u narednoj fusnoti). Ovo višegodišnje iskustvo, posebno pitanja u diskusijama nakon predavanja su nam temelj za ovakvu ocjenu. 
Prirodne znanosti istražuju i mjere, govore što se zbiva, što uzrokuje ove procese, kamo to vodi. Budući su u priču uključeni čovjek, društva, gospodarstva i države kao temeljni socijalni akteri i tvorci onda je posao društveno-humanističkih znanosti i struka da objasne sociološke i socio-psihološke, polit-ekonomske i druge društvene i ljudske determinante procesa i problema. Potrebnu promjenu ponašanja ljudi ne mogu pripremati kemija i fizika. Misao o društvu i ljudima, sociologijska i ina znanja koja se grade na tome mogu artikulirati rješenja za problem (nadolazeće) duboke klimatske krize. ${ }^{9}$

\section{ODREĐENJE POJMA KLIMATSKE PISMENOSTI}

Pojasnimo, sustavno artikuliranje klimatskog opismenjavanja je u ranoj inicijalnoj fazi. Formalne i neformalne prakse kojima je cilj naučiti ljude o čemu je riječ te odgojiti i osvijestiti ih koliko je ova pismenost važna su u povojima. Logično, empirijskih istraživanja o rezultatima ovog odgojno-obrazovnog procesa još nema. ${ }^{10}$

Uvodno, pogledajmo što se misli pod pojmom opće pismenosti. Pismenost (engl. literacy) proizlazi iz latinske riječi literatus, učen čovjek. Poimanje i uloga pismenosti su se mijenjali tijekom povijesti, da bi u zadnjem desetljeću pod utjecajem razvoja informacijsko-komunikacijske tehnologije stekli i neke nove dimenzije. Nekada je pismenost, kao vještina, bila potrebna ljudima koji se školuju, otvarala im je put do stjecanja znanja, danas je zbog promijenjene organiziranosti društva potrebna svima. Razumijevanje pojma pismenosti s obzirom na povijest može podijeliti na etape: a. do 1950. godine podrazumijevala se alfabetska pismenost; b. iza 1950. godine govori se o funkcionalnoj pismenosti kao širem pojmu.

Smatra se da je funkcionalna pismenost svakog pojedinca minimalna sposobnost upotrebe pisane komunikacije u cilju djelovanja u društvu, pa kao takva predstavlja bitni uvjet za sudjelovanje pojedinca u demokraciji i ekonomiji kao i u kulturnoj integraciji pojedinog društva. Funkcionalna pismenost je praksa koja omogućava pojedincu da čita, sluša i govori jezik, odnosno to je kompetencija koja nadilazi gramatička, pravopisna i semantička pravila, a sve u cilju da se pojedinac time uspješno služi u društvu i u svakodnevnom životu.

UNESCO (1978) definira pojam funkcionalne pismenosti na način da osoba koja je funkcionalno opismenjena mora biti u stanju učestvovati u svim aktivnostima gdje se zahtijeva pismenost za efikasno funkcioniranje njene grupe ili zajednice. Funkcionalno pismena je ona osoba koja osim čitanja i pisanja ima sposobnost razumijevanja pisanih

9 U hrvatskim uvjetima smo 2006. godine napisali prvi priručnik koji predstavlja pionirski prilog podizanju razine klimatske pismenosti u Hrvatskoj. Vidi: Lay et al., 2007.

Ova sažeta knjiga (83 str.) bila je dio obrazovne produkcije na projektu „Osposobljavanje za provedbu Okvirne konvencije UN o promjeni klime i Kyoto protokola u Republici Hrvatskoj" - LIFE 3 TCY/ $\mathrm{CRO} / 000029$.

10 Kao argument za ovu tvrdnju dovoljno je pretražiti internetske stranice na temu „research on practice of climate change literacy“ ili slično. 
materijala i mogućnost primjene u svakodnevnom životu, u svom domu, na poslu i u društvu.

U relativno oskudnoj literaturi ${ }^{11} \mathrm{o}$ „klimatskoj pismenosti“ naišli smo na jednu definiciju koja nam se čini sadržajna i ispisana razumljivim jezikom, a koja je, dakle, društveno korisna.

Ova definicija glasi: „Klimatski pismena osoba:

a. razumije osnovna načela planetarnog klimatskog sustava;

b. zna kako doći do znanstveno vjerodostojnih informacija o klimatskim promjenama;

c. komunicira o klimi i klimatskim promjenama na adekvatan i razumljiv način;

d. sposobna je učiniti utemeljene i odgovorne odluke u vezi s akcijama koje mogu utjecati na klimu. ${ }^{12}$

Najkraće, klimatski pismeni su oni koji informiranošću, znanjem i postupanjem vezanim za klimu i klimatske promjene mogu unaprjeđivati kvalitetu življenja na određenom teritoriju“" (NOAA, 2009). Dakle, klimatska pismenost podrazumijeva znanje i razumijevanje, komuniciranje o stečenim znanjima i spoznajama i najvažnije - donošenje odluka za djelovanje.

Kada ovakvo shvaćanje klimatske pismenosti transferiramo u obrazovne i djelatne prakse hrvatskog društva ili šire, moderni svijet u cjelini - posve je jasno kako je ona slabo razvijena i slabo rasprostranjena, posebno u dijelu pretvaranja znanja u donošenje odluka. Ne može se danas niti od jednog pojedinca očekivati da razumije u detalje sve o znanstvenim fundamentalnim znanjima o klimi koja su potka klimatske pismenosti. To nije niti potrebno. Potrebna je elementarna informiranost. Moramo znati da porast temperature tjera biljne i životinjske vrste na migriranje u širim prostorima. Znamo da nema života bez vode, bez kiše. Globalno zagrijavanje smanjuje količinu padalina na određenim prostorima. Moramo znati, makar nismo prirodni znanstvenici, da masivno topljenje leda podiže razinu mora, njegov sastav, a sutra i smjer morskih struja.

Uzgred, klima je interdisciplinarna tema za doživotno učenje, posebno o tome kako ljudi utječu na ekološke sustave na Zemlji. Za očekivati je da će dio ljudi, posebno mladih generacija koji će posljedice klimatskih promjena trpjeti u rastućoj mjeri u usporedbi s današnjim starijim generacijama (npr. onima iznad 65 godina) htjeti znati više i o tome

11 Jednostavni unos ovog pojma u internetsko pretraživanje (engl. climate change literacy) potvrđuje ovu tvrdnju. To u prvi mah začuđuje, ali kada se dublje uđe u temu postaje jasno da je već to indikator da su ukupna artikulacija pojma klimatske pismenosti i prakse njenog odgojno-obrazovnog širenja 2016. godine povojima, na početku definiranja i prakticiranja.

12 Današnji pojedinci i društva nisu, to je naša ocjena i stav, elementarno pripremljeni za djelovanje na području zaustavljanja globalnog zagrijavanja i ovladavanja uzorcima i posljedicama klimatskih promjena. Na neki način klimatski nepismeni su slijepi, gluhi i pasivni, temeljito bez pokretačkog motiva, bez poduzetnosti da nešto promjene na polju negativnih trendova vezanih za globalno zagrijavanje. 
(NOAA, 2009). Uvidi u klimatske znanstvene spoznaje će se širiti. Civilne udruge u nekim se razvijenim zemljama već sustavno organiziraju i šire ova znanja, spoznaje i klimatsku pismenost. ${ }^{13}$

Sad je jasnije što bi to bila klimatska pismenost. Naredno poglavlje nudi viđenje i kratku analizu osnovnih socijetalnih, kontekstualnih i općih kognitivnih prepreka razvoju / porastu klimatske pismenosti ili, drugačije rečeno, možda preciznije, pismenosti za klimatske promjene (engl. climate changes literacy). Naša je pretpostavka da će ova tema koja je „orijentirana na budućnost“ biti izuzetno znanstveno i društveno aktualna narednih nekoliko desetljeća. U medijskim člancima smo našli informaciju kako će nove profesije vezane za rješavanje problema klimatskih promjena i njenih posljedica biti tražene na tržištu.

\section{NEKE OSNOVNE ZAPREKE RAZVOJU I PORASTU KLIMATSKE PISMENOSTI POJEDINACA I DRUŠTAVA}

Ovdje u obliku skice, bez podrobnije elaboracije prikazujemo nekoliko osnovnih zapreka. Držimo da one u svom temelju ne ubrzavaju već obeshrabruju, usporavaju ili čak onemogućuju razvoj i širenje klimatske pismenosti.

\subsection{Percepcija modernih ljudi spava, kasni za činjenicama, globalno zagrijavanje- klimatske promjene su - kažu oni - problem budućnosti!}

Globalno zagrijavanje i klimatske promjene su procesi koji se na planetu Zemlji događaju sada i ovdje. To nije pitanje budućnosti. To je pitanje današnjice s velikim šansama da iz godine u godinu postaje sve teže, razornije i opasnije po Život i ljudsku civilizaciju. Ljudski um i podsvjesne razine ljudskog bića (instinkti) reagiraju brzo samo na hitne, opasne, sadašnje neposredne podražaje, na primjer na ugrozu Života. Svi ostali podražaji se svrstavaju u kategoriju problema na koje se ne mora reagirati odmah, reakcija se može odgoditi i odgađati do neke buduće točke $\mathrm{X}$ u vremenu.

Osnovno obilježje čitanja problema globalnog zagrijavanja i klimatskih promjena koje su ovime uzrokovane danas imaju upravo takav osnovni status - „možemo odgoditi reakciju na ovaj problem“. Razlog tomu je jednostavan. Ne vidi se umom, srcem, duhom - time čime ljudsko biće nešto uopće može „vidjeti“, napokon niti fizički - očima da je to po svome karakteru, procesu, dinamici proces i problem koji se odvija danas i ovdje. Ne vidi se, žmiri se, ne shvaća se. Ako se ne reagira danas i ovdje, ne shvaća se da će u opsegu i težini problemi samo narasti i po opsegu i po intenzitetu. Problemi s klimom kreću se k razinama na kojima će ih biti sve teže i skuplje rješavati. Ili, još pogubnije, problemi će preći „točku preokreta“ i više ih neće biti moguće riješiti na dosadašnje načine. Tada više u ukupnosti nećemo na planetu moći u ukupnosti uživati u klimi kao „općem dobru“ i živjeti na dosadašnji, klimatski komforan način.

13 Vidi npr. URL: http://www.climatechangeliteracy.com/people-power.html 
Na ljudima suvremenog doba je zadaća broj jedan - prestati žmiriti i problem globalnog zagrijavanja i njegovih posljedica koji je sada i ovdje, zbog komocije, pasivnosti, odsustva mudrosti i volje za preventivnim djelovanjem izmiještati u neku budućnost. Usred problema smo, samo što još ne gori sama kuća, nego tek dvorište.

\subsection{Učinkovit i organizirani politički globalni odgovor na problem globalnog zagri- javanja je godinama izostajao. To je, najkraće rečeno, odgodilo ili barem usporilo razvoj i širenje klimatske pismenosti.}

Kakav je do sada bio politički odgovor modernog svijeta na taj trend i globalni, novi i opasni izazov? U Rio de Janeiru je 1992. godine na Earth Summitu donesen dokument "Okvirna konvencija o klimatskim promjenama“ (engl. UNFCCC), koja je stupila na snagu 1994. godine. Na konferenciji COP ${ }^{14}$ u Kyotu u Japanu 1997. donosi se, tada se mislilo, obećavajući Protokol iz Kyota. Ovaj prijedlog postupanja sa stakleničkim plinovima u društvima i državama svijeta prema vlastitim propozicijama stupa na snagu prije 11 godina, 16. 2. 2005. godine. Posljednjih deset, rekli smo, najtoplijih godina (2005. -2015.) imao je vrlo skromne rezultate na nekim lokalnim razinama, a na planetarnoj razini doživljava neuspjeh.

Ukratko, u četvrt stoljeća koliko je prošlo od spomenute 1992. godine političke elite država svijeta u zadanim okvirima dominantno kapitalističke civilizacije nisu izgradile nikakav čvrsti i učinkoviti sustav odluka i smanjenja emisija stakleničkih plinova, globalnog zagrijavanja te tako snižavanja poticaja za klimatske promjene. U takvim slabašnim političkim okvirima, uz spomenutu percepciju pitanja klimatskih promjena kao pitanja budućnosti, a ne sadašnjosti, razvoj i širenje klimatske pismenosti nije imalo organiziranu i učinkovitu podršku.

Krajem 2015. održana je u Parizu konferencija UN o klimatskim promjenama, tzv. COP 21. Globalni dogovor koji je tamo postignut najviše je što se moglo postići u modernom, labavom i krhkom političkom ustroju svijeta. Pariški sporazum o klimi predstavlja pravno obvezujući sporazum za sve stranke konvencije kada ga ratificira 55 stranaka koje kumulativno čine 55\% ukupne emisije stakleničkih plinova prema zadnjim raspoloživim podacima. To znači da sporazum trebaju ratificirati najveći proizvođači onečišćenja da bi stupio na snagu. Nadajmo se da tu neće biti odugovlačenja kao kod Protokola iz Kyota. Treba reći da, iako je u cjelini pravno obvezujući, sporazum ima pojedine elemente koji su snažniji ili više obvezuju u provedbenom smislu od nekih drugih. U osnovi, PS počiva na tri stupa kojima se jača globalni odgovor na klimatske promjene: (1) dugoročni cilj iskazan u obliku globalnog prosječnog porasta temperature ispod $2^{\circ} \mathrm{C}$ i nastojanja da se ograniči do $1,5^{\circ} \mathrm{C}$; (2) povećanje sposobnosti svih država

$14 \mathrm{COP}=$ Konferencija učesnika (engl. Conference of the Parties). Prva konferencija COP 1 je održana 1995. u Berlinu.

COP 3 bio je u Kyotu 1997. i artikulirao je Kyoto protokol koji je zemlje konkretnije usmjerio na pokušaje smanjenja emisija stakleničkih plinova. COP 15 održan je 2009. u Kopehagenu, očekivanja su bila velika, ali bio je to neproduktivan i jalov pokušaj novog koraka u borbi za bolju klimu. 
za prilagodbu klimatskim promjenama i "nisko-emisijski“ razvoj (važna napomena: ne spominje se pojam „nisko-ugljični“); (3) omogućavanje financijskih tokova koji su u razmjeru s potrebama za ostvarenjem „nisko-emisijskog razvoja“. Na taj je način globalni odgovor na problem konačno postao organiziraniji. Nudi šansu za mijenjanje. Za očekivati je da će u takvoj situaciji i posao odgoja i obrazovanja u cilju razvijanja klimatske pismenosti u narednim godinama kao i važna ljudska djelatnost dobiti podršku i vjetar u leđa za brži razvoj i brže širenje.

\subsection{Klimatsko opismenjavanje - organizacija motivacije za tako nešto kroz konkretne opomene, nevolje i patnje - vrlo malo kroz anticipaciju}

Ako ništa drugo, ljudsku će psihu, nevolje i štete, gledano vrlo ogoljeno, ali ne i netočno, najbrže i najjače poučiti da je promjena nužna. Klimatsko opismenjavanje na silu i često vrlo učinkovito zbiva se u situacijama kada neki konkretan oblik klimatskih promjena oduzima živote, šteti zdravlju i opstanku (prehrana, stanovanje i sl.), nanosi štetu imovini i mirnom i sigurnom življenju.

Može li se klimatska pismenost razvijati i širiti na temelju anticipacije korisnosti od nje ubuduće? Naša ocjena je jednostavna - nažalost, vrlo malo ili ništa. Takav je prosječan ljudski um, takva je prosječna ljudska psiha. Ako je tako, jedna od zapreka razvoju širenja klimatske pismenosti je nedostatna „orijentacija na budućnost“, oslanjanje na korisnost i potrebu za snaženjem klimatske pismenost sada i ovdje - za sutra. Tko živi planirajući sutra, prekosutra, deset godina unaprijed? Znanstvene analize psihologa i socijalnih ekologa su pokazale - veoma mali broj ljudi.

\section{4. „Prevodenje“ znanstvenih nalaza, podataka i spoznaja o globalnom zagrijavanju $i$ klimatskim promjenama „običnim“ stanovnicima svijeta $i$ pojedinih društava $i$ država je neučinkovito ${ }^{15}$}

Komplicirana znanja i podaci nisu u dometu spoznaje „običnih“ ljudi. Potrebno je „prevođenje“. Djeluje li ono učinkovito? Naša je ocjena - ne! Čiji je posao prevođenje i „popularizacija“" znanstvenih nalaza i spoznaja o klimatskim promjenama? Je li to posao znanstvenika? Primarno nije. No, oni bi mogli mnogo pomoći. Razvoj i širenje klimatske pismenosti je posao onih koji stvaraju vrijednosti i onih koji poučavaju u znanjima, dakle edukatora koji obrazuju. Učenje kao „vođenje“ ljudi u svijesti, vrijednostima i znanjima. Gdje su nam danas odgajatelji i edukatori za tako nešto? Gdje su sustavni procesi edukacije za klimatsku pismenost?

\section{ZAKLJUČNE NAPOMENE}

Razvoj i širenje pismenosti za klimatske promjene je pretpostavka učinkovitijeg djelovanja na poslu ovladavanja globalnim zagrijavanjem i klimatskim promjenama. Sazrela je potreba za sustavnim planetarnim, sustavnim, paralelno institucionalnim i vaninstitucionalnim klimatskim opismenjivanjem pojedinaca i društava.

15 Vidi elaboraciju u: Moser i Dilling (2007) 
Ljudska rasa je kroz svoju povijest proizvodila znanja i vještine koja su rješavala probleme koje je život donosio. Stvarane su uvijek iznova nove i nove tehnike i tehnologije koje su pomagale da se živi lakše, da se proizvodi više, da se poveća kvaliteta življenja. Sada smo pred novim problemom i istom zadaćom. On je tim teži jer se globalno zagrijavanje i težnja za stalnim rastom produkcije materijalnih dobara dubinski uzročnoposljedično povezani i po svemu sudeći temeljno proturječne.

Valja proizvoditi nove spoznaje i nova znanja o globalnom zagrijavanju, klimatskim promjenama, konceptualnim pretpostavkama i načinima smanjenja proizvodnje stakleničkih plinova, reorganizaciji ukupnog društvenog i pojedinačnog života u funkciji toga cilja.

Valja kroz klimatsko opismenjavanje pokretati procese participacije i uključivanja u rješavanje uzroka klimatskih promjena u svakodnevnici, „na terenu“, danas i ovdje. Bez ovog uključivanja (ljudi, udruga građana, institucija, države, poduzetnika, medija, crkve...) nema uspjeha već slijedi propadanje. ${ }^{16}$ Povezivanje i ujedinjavanje, uključivanje socijalnih snaga oko ovog golemog problema, a ne isključivanje i njihovo „rasparčavanje“ je ključ uspješne promjene. Širenje broja opismenjenih u bilo čemu je samo po sebi pokret inkluzije, uključivanja sve većeg broja ljudi, nikako ne njihovo ostavljanje na rubu, isključivanje izvan procesa.

Uzgred, pitajmo se - u duhu dijaloga - koliko za sebe samu, samoga smatrate da ste klimatski pismeni? Pojam više tajna, objasnili smo ga. Sadržaj je jasan. Prilika je da izmjerite i ocijenite vlastiti klimatsku pismenost i ako s postojećom razinom niste zadovoljni da je u godinama koje dolaze unaprijedite.

Klimatski nepismeni pojedinci i društva ne znaju niti „pročitati“ što se $s$ to danas s globalnim zagrijavanjem i klimom na planetarnoj razini zbiva, što klimatske promjene uzrokuje, te kako u tome sudjeluje ljudska rasa i od nje smišljene i stvorene vrijednosti življenja, proizvedene tehnologije i suvremeni oblici organizacije života. Što nam globalno zagrijavanje danas donosi, koje nam sve posljedice stvara po život, zdravlje, mir, imovinu i opstanak sam? U kojem smjeru se problem globalnog zagrijavanja kreće i što možemo očekivati za deset, dvadeset, trideset godina ako se sve nastavi „po starom“, onako kako svi zajedno djelujemo danas? Znamo li to? Imamo li spoznajne alate i metode da to shvatimo?

Zaključno, klimatski nepismeni pojedinci i društva naprosto niti ne znaju da su klimatski nepismeni. Ako ih je mnogo, ako o njima zavisi izmjena negativnih i po klimu na Zemlji razornih trendova promjena - onda smo svi skupa u velikoj neprilici.

Klimatska pismenost je novonastali oblik potrebne funkcionalne pismenosti. Bez nje nema učinkovitog sudjelovanja ljudi u promjeni koja je ljudskoj rasi, modernoj civilizaciji i reprodukciji života na postojećoj kvalitativnoj razini neophodna.

16 Važnost inkluzivnosti (uključivanja) na razini razvoja država i društava tematiziraju vrlo argumentirano Acemoglu i Robinson (2014). 
Ponovimo, tema klimatske pismenosti - mada još nije odviše u intelektualnoj i političkoj „modi“ - po našoj procjeni je stručno, znanstveno i životno vrlo značajna. Socijalna ekologija, a posebno novonastala sociologija klimatskih promjena, ima priliku u tome dati svoj znalački spoznajni doprinos.

\section{LITERATURA}

Acemoglu, D. i Robinson J. A. (2014). Zašto narodi propadaju. Beograd: Clio.

Climate Change - Synthesis Report. (2014). IPCC.

Klein, N. (2015). Ovo mijenja sve - Kapitalizam protiv klime. Zagreb: VBZ.

Lay, V., Kufrin, K., Puđak, J. (2007). Kap preko ruba čaše - Klimatske promjene - svijet i Hrvatska. Zagreb: Hrvatski centar „Znanje za okoliš“.

Moser, S. i Dilling, L. (2007). Communicating Climate Changes: Closing Science Action Gap. U: Moser S. i Dilling. L. (ur.), Creating a Climate for Change (str. 161174). Cambridge: Cambridge University Press.

NOAA (2009). Climate Literacy: The Essential Principles of Climate Sciences. NOAA Guide. URL: http://oceanservice.noaa.gov/education/literacy/climate_literacy.pdf (28.2.2017.)

NOAA (2016). National Centers for Environmental Information. State of the Climate: Global Analysis for July 2016. URL: https://www.ncdc.noaa.gov/sotc/global/201607 (03.03.2017.) 


\title{
CLIMATE LITERACY: OBSTACLES TO THE DEVELOPMENT AND SPREAD OF CLIMATE LITERACY
}

\author{
Vladimir Lay
}

\begin{abstract}
The focus of this paper is the relation between global warming and climate change, as the biggest problems of modern civilization, and the development of climate literacy, as one of the major prerequisites and tools for conquering this problem. The topic of climate literacy is being introduced in formal and informal education all over the world. As it is still in its preliminary, introductory phase, we do not have enough data to discuss its impacts in practice.

A compelling definition of climate literacy, which we consider useful for its future practice, is as follows: "A climate-literate person: a) understands the essential principles of Earth's climate system; b) knows how to assess scientifically credible information about climate; c) communicates about climate and climate change in a meaningful way; and d) is able to make informed and responsible decisions with regard to actions that may affect climate" (NOAA, 2009). According to our assumptions, climate literacy of modern civilization is very low. We have no empirical research on which to base our assumptions as there are almost no research conducted on this topic. However, systemic changes to the worse with regards to global warming can serve as an indirect indication. Climate literacy of modern societies does not yet encourage significant technological, organizational and social changes towards the reduction of greenhouse gases. Major obstacles for the development of climate literacy from the sociological standpoint are as follows: a) The perception of modern people is narrow in its scope and lags behind the facts as they claim that global warming and climate change are issues of the future. Climate literacy should, according to them, be dealt with when the problem becomes more urgent; $b$ ) An efficient and organized global political response to the issue of global warming has been non-existent for years. This has either postponed or at least slowed down the development and spread of climate literacy; c) The development of climate literacy will be motivated more by growing negative consequences of global warming than by anticipating future consequences of climate change; and d) The "translation" of scientific findings, data and insights about global warming and climate change for "ordinary" citizens is inefficient.
\end{abstract}

Key words: climate literacy, global warming, climate change

\section{KLIMATISCHER ALPHABETISMUS: ANALYSE DER GRUNDLEGENDEN BARRIEREN FÜR DIE ENTWICKLUNG UND VERBREITUNG DES KLIMATISCHEN ALPHABETISMUS}

\author{
Vladimir Lay
}

\section{Zusammenfassung}

Im Mittelpunkt der Aufmerksamkeit steht in diesem Artikel das Verhältnis des Prozesses der wachsenden globalen Erwärmung und des Klimawandels, nämlich eines der größten Probleme der zeitgenössischen Zivilisation einerseits und der Entwicklung des klimatischen Alphabetismus, als eine der Hauptvoraussetzungen und Werkzeug zur Beherrschung dieses Problems andererseits. Das Thema des klimatischen Alphabetismus ist heute in der Iinitiierungsphase in formellen und nicht formellen Bildungspraxen in der Welt. Logischerweise existieren in dieser Phase noch keine Ergebnisse systematischer Forschung dieser Praxen.

Die Definition des klimatischen Alphabetismus, die wir für überzeugend und nützlich für die zukünftige Praktik der klimatischen Alphabetisierung halten, lautet : "Eine klimatisch alphabetisierte Person: a) versteht die Grundprinzipien des Klimasystems auf dem Planeten ; b) weiß, wie man an wissenschaftlich glaubwürdige informationen über den Klimawandel gelangt; c) kommuniziert über das Klima und den Klimawandel auf eine adäquate und verständliche Art und Weise; d) ist fähig, begründete und ve- 
rantwortungsvolle Entscheidungen zu treffen hinsichtlich der Aktionen, die das Klima beeinflußen können im Sinne der Reduzierung von Treibhausgasen und Senkung der globalen Erwärmung" (NOAA, 2009). Durchschnittlicher klimatischer Alphabetismus befindet sich in der zeitgenössischen Zivilisation, unserer Einschätzung nach, auf einem niedrigen Niveau. Dazu haben wir keine Bestätigung in Form von Forschungsergebnissen, weil es sie zu diesem Thema fast gar nicht gibt. Eine systematische Verschlechterung auf dem Gebiet der globalen Erwärmung bestätigt diese Einschätzung aber indirekt. Ein klimatischer Alphabetismus von zeitgenössischen Gesellschaften verursacht immer noch keine wesentlichen technologischen, organisatorischen und gesellschaftlichen Veränderungen zwecks Reduktion von Treibhausgasen. Die grundlegenden Barrieren für die Entwicklung des klimatischen Alphabetismus, vom soziologischen Standpunkt gesehen, sind: a) Der moderne Mensch hat ein enges Wahrnehmungsfeld und hinkt den Tatsachen hinterher. Die globale Erwärmung und der Klimawandel seien für ihn Probleme der Zukunft! „Wir befassen uns mit der klimatischen Alphabetisierung, sobald dies aktuell ist"; b) Eine effiziente organisierte politische globale Antwort auf das Problem der globalen Erwärmung blieb jahrelang aus. Das hat kurzum die Entwicklung und Verbreitung des klimatischen Alphabetismus hinausgezögert oder wenigsten verlangsamt; c) Klimatische Alphabetisierung wird eher durch wachsende negative Folgen der globalen Erwärmung motiviert werden als durch das Antizipieren eines zukünftigen Klimawandels; d) Das „Übersetzen“ wissenschaftlicher Befunde, Daten und Erkenntnisse über die globale Erwärmung und den Klimawandel ist für „Normalbürger" ineffizient.

Schlüsselwörter: klimatischer Alphabetismus, globale Erwärmung, Klimawandel 